\title{
Preliminary pharmaceutico-analytical study of Mukhadooshikaharalepa Churna
}

\author{
Research Article
}

\section{Ambika S1*, Gazala Hussain²}

1. PG Scholar, 2. Associate Professor, Department of Rasashastra and Bhaishajya Kalpana, Sri Dharmasthala Manjunatheshwara College of Ayurveda \& Hospital, Hassan.

\begin{abstract}
Introduction: Lepa is a bahirparimarjana chikitsa that helps in bringing samyata in sthanika dosha and dhatu. Many lepa are mentioned in Ayurveda pharmaceutics for the treatment of mukhadooshika. Among it, one is a combination of Lodhra, Kustumburu, Vacha, Vatapallava, and Narikelashuktya. Mukhadooshika is a type of kshudraroga, featuring the formation of pidaka on face. The symptoms of mukhadooshika resembles with acne vulgaris. Aim: An attempt is made to analyze the physico-chemical parameters of the mukhadooshikahara lepa churna. Materials and methods: The pharmaceutical preparation is easy and simple with easily available ingredients. The organoleptic characters like appearance, odour, taste and physico-chemical parameters like $\mathrm{pH}$, total ash. Water Soluble ash, Alcohol soluble extractives, Water soluble extractives, loss on drying and HPTLC were carried out. Observations and results: The obtained results were discussed in the present paper. Discussion and conclusion: Mukhadooshikahara lepa churna is a simple preparation and can be prepared by easily available drugs. HPTLC fingerprinting at different wavelengths was carried out. At $254 \mathrm{~nm}, 366 \mathrm{~nm}$ and $620 \mathrm{~nm} \mathrm{11,8}$ and 10 peaks were found with different retention factor starting from 0.02 to $0.80,0.03$ to 0.096 and 0.07 to 0.80 respectively. The analytical study findings can be taken as a preliminary standard for mukhadooshikahara lepa churna.
\end{abstract}

Key Words: Lepa, Mukhadooshika, Kshudraroga, Ayurveda Pharmaceutics.

\section{Introduction}

Topical applications have been given significance in Ayurveda therapeutics and its emphasis is seen in classical texts of Ayurveda. Lepa is a bahirparimarjana chikitsa that helps in bringing samyata in sthanika dosha and dhatu (1)

Many lepa are mentioned in Ayurveda pharmaceutics for the treatment of mukhadooshika. Among it, one is a combination of Lodhra, Kustumburu, Vacha, Vatapallava, and Narikelashuktya (2) (Table 1).

Mukhadooshika is a type of kshudraroga, featuring the formation of pidaka on face (3). The symptoms of mukhadooshika resembles with acne vulgaris.

Wide range of treatment exists for Acne vulgaris which include both topical application and oral medicine. But side effects like skin irritation, contact dermatitis, photo sensitivity by topical application are often noticed. So there is an intense need for potential, well tolerated treatment which can limit the disease without affecting the beauty and reduce its psychological impact. While mentioning the treatment

\section{* Corresponding Author:}

\section{Ambika S}

Post Graduate Scholar,

Department of Rasashastra and Bhaishajya Kalpana,

Sri Dharmasthala Manjunatheshwara College of

Ayurveda Hospital, Hassan. India

Email Id: ambikasudarshan152@gmail.com modalities for Mukhadhooshika all the Acharya of Ayurveda have given importance for lepa (4)

Hence an attempt is made to analyze the physico-chemical parameters of the mukhadooshikahara lepa churna.

\section{Materials and Methods \\ Pharmaceutical study \\ Place of collection of Ingredients}

Lodhra, vacha and dhanyaka were collected from CKKM Pharmacy, Kerala and vatapallava and narikelashuktya from local drug vendor Chikmagalore.

\section{Authentication of Ingredients}

The ingredients

Lodhra, vacha and dhanyaka were authenticated from CKKM Pharmacy Kerala and vatapallava and narikela shuktya were authenticated from the Dravya Guna Department, Sri Dharmasthala Manjunatheshwara College of Ayurveda and Hospital, Hassan, Karnataka. Authentication was done based on macroscopic and microscopic characters, organoleptic features as well as morphological appearance.

\section{Place of study}

Teaching pharmacy, Dept. of Rasashastra and Bhaishajya Kalpana, Sri Dharmasthala Manjunatheshwara College of Ayurveda and Hospital, Hassan, Karnataka.

Mukhadooshika lepa churna was prepared in a single batch in following method. 


\section{Materials}

Apparatus: Khalva yantra (Mortar-pestle), Patra (Vessel), Darvi (Spoon), Tula yantra (Weighing machine), Sieve, Tray, and Mixer.

\section{Method}

Raw Ingredients (Fig 1) of Mukhadooshika hara lepa were taken in equal quantity (Table 1). Ingredients were pounded separately (5). Ingredients were sieved to obtain coarse powder of churna.(Fig 2)

\begin{tabular}{|c|c|}
\hline SI.No & Sanskrit Name \\
\hline 1 & Lodhra \\
\hline 2 & Kustumburu \\
\hline 3 & Vacha \\
\hline 4 & Vata \\
\hline 5 & Narikela \\
\hline
\end{tabular}

Table 1: Ingredients with quantity

Botanical Name
Symplocos racemosa Roxb.
Coriandrum sativum Linn.
Acorus calamus Linn.
Ficus benghalensis Linn.
Cocos nucifera Linn.

Part Used
Bark
Dried seeds
Rhizome
Tender leaves
Inflorescence

Quantity
$200 \mathrm{~g}$
$200 \mathrm{~g}$
$200 \mathrm{~g}$
$200 \mathrm{~g}$
$200 \mathrm{~g}$

Fig 1: Raw ingredients of mukhadooshikahara lepa curna

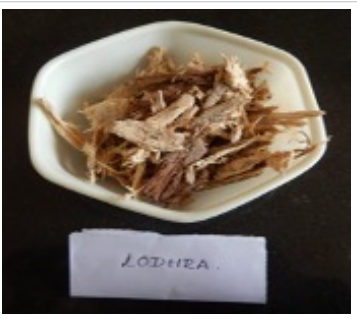

Lodhra

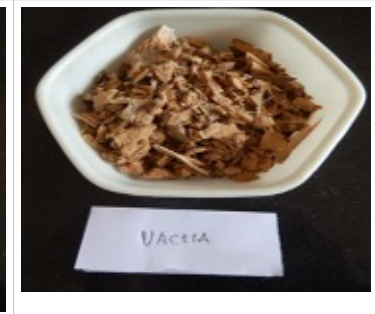

Vacha

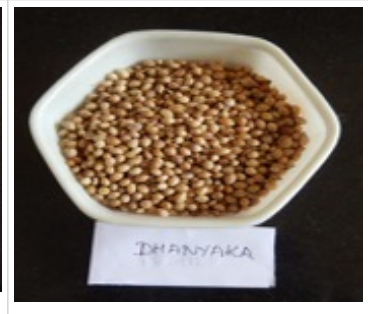

Dhanyaka

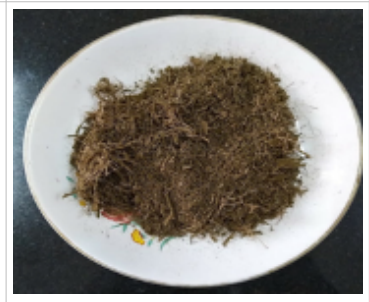

Vatapallava churna

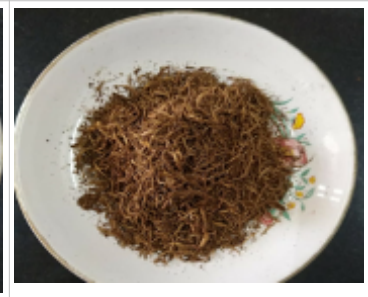

Narikelashuktya churna

Fig 2: preparation of mukhadooshikahara lepa curna

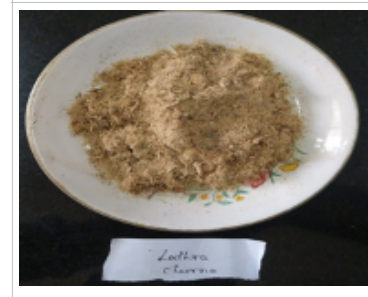

Lodhra Churna

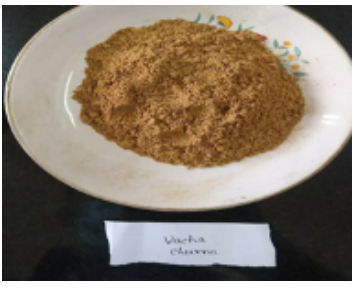

Vacha Churna

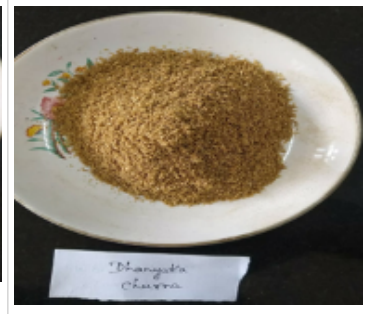

Dhanyaka churna

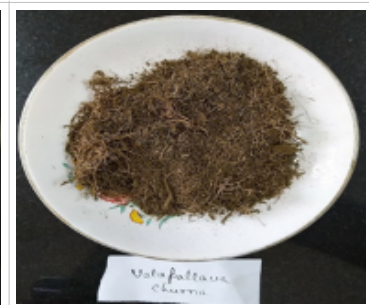

Vatapallava churna

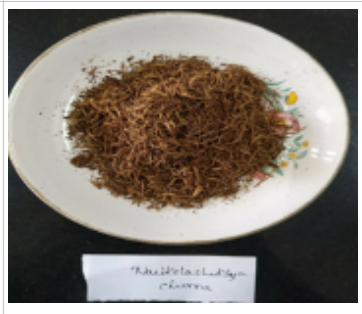

Narikelashuktya churna

\section{Precautions taken}

The ingredients were dried to avoid moisture content. The spilling of drug was avoided while triturating.

\section{Analytical study}

Mukhadooshikahara lepa churna was analyzed by following parameters as per the references available in protocol for testing published by CCRAS

- Morphological evaluation- Organoleptic characters

- Physico-chemical evaluation - Total ash, Acid insoluble ash, Water Soluble ash, Alcohol soluble extractives, Water soluble extractives, $\mathrm{pH}$ and HPTLC

\section{Place of study}

SDM Research Centre of Ayurveda and Allied sciences, Udupi, Karnataka

Date of study: $10-12-2020$ to $25-01-2020$

- Organoleptic characters: This test was done for mukhadooshikahara lepa churna.

- Materials: Mukhadooshikahara lepa churna

- Method: Here, Colour and odour of the samples were examined.
Physico-chemical parameters:

Total Ash (6)

- Materials: Platinum/ silica dish, Crucible, Muffle furnace, Weighing balance, Ashless Filter paper, Mukhadooshikahara lepa Churna

- Method: 2 g of sample was incinerated in a tarred platinum crucible at temperature not exceeding $450^{\circ} \mathrm{C}$ until carbon free ash was obtained. Percentage of ash was calculated with reference to weight of the sample.

\section{Acid insoluble Ash (7)}

- Materials: Beaker, Crucible, Ash less filter paper, Hot plate, Muffle furnace, Desiccators, dil. $\mathrm{HCl}$, Mukhadooshikahara lepa Churna

- Method: To the crucible containing total ash, $25 \mathrm{ml}$ of dilute $\mathrm{HCl}$ was added. The insoluble matter was collected on ash less filter paper (Whatman 41) and washed with hot water until the filtrate was neutral. The filter paper containing the insoluble matter was transferred to the original crucible, dried on a hot plate and ignited to constant weight. The residue was allowed to cool in suitable desiccators for $30 \mathrm{~min}$ and weighed without delay. The content of acid insoluble 
ash was calculated with reference to the air dried drug.

\section{Alcohol soluble extractive (8)}

- Material: Conical flask, Crucible, Hot air oven, Distilled alcohol, Mukhadooshikahara lepa Churna

- Method: $4 \mathrm{~g}$ of the churna was weighed accurately in a glass stoppered flask. $100 \mathrm{ml}$ of distilled Alcohol (approximately 95\%) was added and shaken occasionally for 6 hours. It was allowed to stand for 18 hours. Later, it was filtered rapidly taking care not to lose any solvent. $25 \mathrm{ml}$ of the filtrate was pipetted out in a pre-weighed $100 \mathrm{ml}$ beaker. It was evaporated to dryness on a water bath. Later, it was kept in an air oven at $105^{\circ} \mathrm{C}$ for 6 hours, cooled in desiccators for 30 minutes and weighed. The percentage of Alcohol extractable matter of the sample was calculated. The experiment was repeated twice, and the average value was taken.

\section{Water soluble extractive (9)}

- Material: Conical flask, crucible, hot air oven, distilled water, Mukhadooshikahara lepa Churna

- Method: $4 \mathrm{~g}$ of the curna was weighed accurately in a glass stoppered flask. $100 \mathrm{ml}$ of distilled water was added, shaken occasionally for 6 hours. It was allowed to stand for 18 hours. Later, it was filtered rapidly taking care not to lose any solvent. $25 \mathrm{ml}$ of the filtrate was pipetted out in a pre-weighed $100 \mathrm{ml}$ beaker and evaporate to dryness on a water bath. It was kept in an Hot air oven at $105^{\circ} \mathrm{C}$ for 6 hours, cooled in a desiccator and weighed. The experiment was repeated twice. The average value was taken.

\section{-Determination of $\mathrm{pH}(\mathbf{1 0})$}

- Material: pH meter, Distilled water, Mukhadooshikahara lepa Curna

- Method: Preparation of buffer solutions:

- Standard buffer solution: Dissolved $1 \mathrm{~g}$ of mukhadooshikahara lepa churna of $\mathrm{pH} \mathrm{4,7}$ and 9.2 in $100 \mathrm{ml}$ of distilled water.

- Determination of $\mathrm{pH}: 1 \mathrm{ml}$ of sample was taken and made up to $10 \mathrm{ml}$ with distilled water, stirred well and filtered. The filtrate was used for the experiment. Instrument was switched on. 30 minutes time was given for warming $\mathrm{pH}$ meter. The $\mathrm{pH} 4$ solution was first introduced and the $\mathrm{pH}$ adjusted by using the knob to 4.02 for room temperature $30^{\circ} \mathrm{C}$. The $\mathrm{pH} 7$ solution was introduced and the $\mathrm{pH}$ meter adjusted to 7 by using the knob. The $\mathrm{pH}$ was introduced in 9.2 solutions and checked the $\mathrm{pH}$ reading without adjusting the knob. Then the sample solution was introduced and reading was noted. Repeated the test four times and the average reading were taken as result.

\section{- Loss on drying (11):}

- Material: Drying dish, Hot air oven, Mukhadooshikahara lepa Churna

- A sample of 10 grams of the prepared mukhadooshikahara lepa churna were taken in a tarred evaporating dish and dried at $105^{\circ} \mathrm{C}$ for five hours and weighed. The process of drying and weighing was continued at one-hour interval until difference between two successive weighing corresponded to not more than $0.25 \%$.

- HIGH PERFORMANCE THIN LAYER CHROMATOGRAPHY (HPTLC) (12)

- Material: weighing balance, distilled ethyl alcohol, water bath, HPTLC applicator, Mukhadooshikahara lepa Churna

- Method: 1g of Mukhadooshikahara lepa churna was extracted with $10 \mathrm{ml}$ of alcohol. $5 \mu \mathrm{l}$ and $10 \mu \mathrm{l}$ of the extract were applied on a pre-coated silica gel F254 on aluminum plates to a band width of $7 \mathrm{~mm}$ using Linomat 5 TLC applicator. The plate was developed in Toluene: Ethyl acetate: Formic acid (8: 1: 0.2). The developed plates were visualized in UV 254, 366 , after derivatisation with vanillin-sulphuric acid and scanned under UV 254 and 366. RF (Retention factor), colour of the spots and densinometric scan were recorded.

\section{Observations and Results}

\section{Pharmaceutical observations and results}

This section contains the observation and results made during the preparation of medicine.

Observation of preparation of mukhadooshikahara lepa Curna.The ingredients of mukhadooshikahara lepa were taken washed and dried. Each washed and dried drug was taken of $200 \mathrm{~g}$. Each drug was pounded separately in khalva yantra initially after that grinded in mixer to get coarse form. Lodhra was hard and difficult to pound because of its fibrous nature and there was more loss compared to other drugs. Vacha was comparatively less hard and characteristic odour was observed during churna preparation. Dhanyaka was easy to pound and characteristic odour was observed. Narikela shuktya was light in weight and having more density and easily pounded. All the individual drug powdered mixed homogeneously and $720 \mathrm{~g}$ churna obtained. The final product of churna was light brown colour with characteristic odour because of vacha and dhanyaka

\begin{tabular}{l}
$\begin{array}{c}\text { Analytical Observations an Results } \\
\text { Table 2: Organoleptic Characters of } \\
\text { Mukhadooshikahara churna }\end{array}$ \\
\begin{tabular}{|l|l|l|}
\hline SI & $\begin{array}{l}\text { Organoleptic } \\
\text { Characters }\end{array}$ & $\begin{array}{l}\text { Mukhadooshikahara } \\
\text { lepa churna }\end{array}$ \\
\hline 1 & Colour & Brownish white \\
\hline 2 & Odour & Characteristic smell \\
\hline 3 & Consistency & Solid \\
\hline 4 & Taste & Astringent, pungent \\
\hline
\end{tabular} \\
\hline
\end{tabular}

Table 3: Physico-chemical parameters of Mukhadooshikahara churna

\begin{tabular}{l|l|} 
Parameters & $\begin{array}{l}\text { Results n=3 \%w/w } \\
\text { Mukhadhooshikahara } \\
\text { curna }\end{array}$ \\
\hline $\mathrm{pH}$ & 5.69 \\
\hline Loss on drying (Avg \pm SEM) & $7.21 \pm 0.01$ \\
\hline Total ash (Avg \pm SEM) & $9.99 \pm 0.02$
\end{tabular}


Ambika S et.al., Preliminary pharmaceutico-analytical Study of Mukhadooshikaharalepa Churna

$\begin{array}{ll}\text { Acid insoluble ash }(\mathrm{Avg} \pm \mathrm{SEM}) & 1.67 \pm 0.02\end{array}$

Water soluble ash $($ Avg \pm SEM $)$

$2.77 \pm 0.01$

Alcohol soluble extractive (Avg

$6.50 \pm 0.01$

\pm SEM)

Water soluble extractive (Avg \pm

SEM)

$11.14 \pm 0.01$

\section{Results of HPTLC}

Fig 3: HPTLC photo-documentation ethanol extract of mukhadooshikahara curna

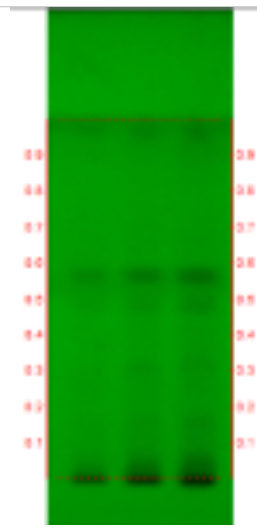

Short UV

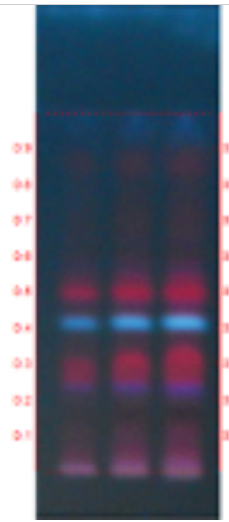

Long UV

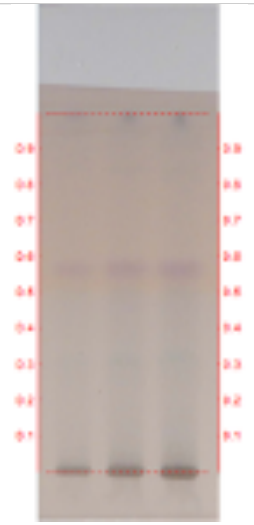

Under white light (after derivatisation)

\begin{tabular}{|c|c|c|}
\hline Peak & $\begin{array}{c}\text { Maximum position } \\
\text { (Retention Factor) }\end{array}$ & \% Area \\
\hline 1 & 0.02 & 11.12 \\
\hline 2 & 0.07 & 1.47 \\
\hline 3 & 0.20 & 8.57 \\
\hline 4 & 0.27 & 1.48 \\
\hline 5 & 0.39 & 5.76 \\
\hline 6 & 0.43 & 1.76 \\
\hline 7 & 0.47 & 1.60 \\
\hline 8 & 0.54 & 17.54 \\
\hline 9 & 0.64 & 44.50 \\
\hline 10 & 0.75 & 4.19 \\
\hline 11 & 0.80 & 2.02 \\
\hline
\end{tabular}

Figure 5: Densinometric scan of Mukhadooshikahara churna at 366nm

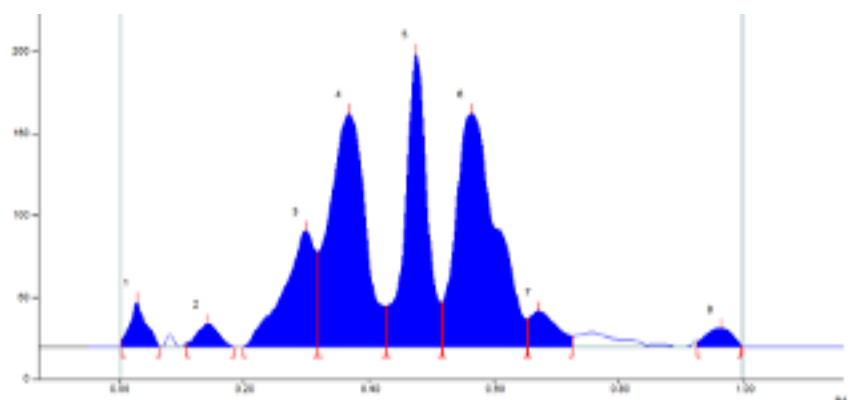

Table 4: RF value of Mukhadooshikahara lepa churna

\begin{tabular}{|l|l|l|}
\hline Short UV & Long UV & $\begin{array}{l}\text { Under wh i t e } \\
\text { ligh t } \begin{array}{c}\text { (a f t r r } \\
\text { derivatisation) }\end{array}\end{array}$ \\
\hline 0.16 (Green) & - & - \\
\hline- & 0.18 (FD. red) & - \\
\hline- & 0.23 (FD. purple) & - \\
\hline 0.30 (Green) & 0.30 (FD. red) & 0.30 (L. Purple) \\
\hline- & 0.42 (F. blue) & - \\
\hline 0.48 (Green) & - & - \\
\hline- & 0.50 (FD. red) & - \\
\hline- & 0.54 (FD. red) & - \\
\hline 0.58 (D. green) & - & 0.58 (D. Purple) \\
\hline
\end{tabular}

*F - fluorescent; D - dark; L - light

Figure 4: Densinometric scan of Mukhadooshikahara churna at 254nm

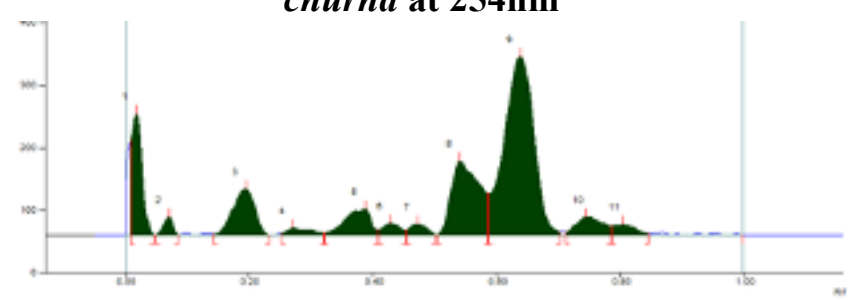

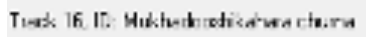

\begin{tabular}{|c|c|c|c|c|c|c|c|c|c|}
\hline Pcak & $\begin{array}{c}\text { Start } \\
\text { Position }\end{array}$ & $\begin{array}{l}\text { 3tart } \\
\text { Hesight }\end{array}$ & $\underset{\text { Puxilian }}{\operatorname{Max}}$ & $\begin{array}{c}\text { Max } \\
\text { Heightit }\end{array}$ & $\underset{\xi}{\operatorname{Max}}$ & $\begin{array}{l}\text { End } \\
\text { Poritien }\end{array}$ & $\left|\begin{array}{c}\text { End } \\
\text { Hexightit }\end{array}\right|$ & Area & $\underset{\$}{\text { Area }}$ \\
\hline 1 & $0.01 \mathrm{Ft}^{\mathrm{t}}$ & $151.6 \mathrm{Al}$ & $2.02 \mathrm{Rf}$ & 190.920 & $20.14 \%$ & $0.05 \mathrm{Rt}^{\mathrm{t}}$ & 2.5 AN & $2551.2 \mathrm{AJ}$ & $11.12 \%$ \\
\hline 2 & $0.05 \mathrm{R}$ & $0.3 \mathrm{AL}$ & $.07 \mathrm{RI}$ & $298+U$ & $358 \%$ & $0.09 \mathrm{R}$ & S.4 ALI & $3254 \mathrm{AJJ}$ & $1.47 \%$ \\
\hline 3 & $0.44 \mathrm{kt}$ & $1.2 \mathrm{AN}$ & $7.20 R t$ & 74240 & $0.00 \%$ & $025 \mathrm{RA}^{-1}$ & $9.0 \mathrm{AN}$ & $1097 \mathrm{ANJ}$ & $0.57 \%$ \\
\hline 4 & $0.25 \mathrm{nt}$ & $3.4 \mathrm{AL}$ & $0.27 \mathrm{Rf}$ & $11.7 \pm 4$ & $1.40 \mathrm{~s}$ & $0.32 \mathrm{R}^{4}$ & $3.4 \mathrm{AU}$ & $3279 \mathrm{AJ}$ & $1.43 \%$ \\
\hline 5 & $\mathrm{a} \times 2 \mathrm{H}+$ & SBAL & 9.301 & $4: 5$ AU & $49 / \%$ & $041 \mathrm{Ht}$ & 55 All & 1275 u A s & $5 n 8 \%$ \\
\hline 5 & $0.41 \mathrm{RA}$ & Q.7 AU & $2.43 \mathrm{Rf}$ & $1922 \mathrm{U}$ & $229 \%$ & $0.45 \mathrm{Rt}^{\mathrm{t}}$ & $7.9 \mathrm{AU}$ & $3900 \mathrm{AJ}$ & $1.76 \%$ \\
\hline 7 & $0.45 \mathrm{Al}$ & $81 \mathrm{AL}$ & $\$ .47 \mathrm{RI}$ & 17.724 & $211 \%$ & aso $\mathrm{Al}$ & S.SALI & 355, AuJ & $182 \%$ \\
\hline 8 & $0.50 \mathrm{RA}$ & $0.4 \mathrm{AN}$ & 1.54 Rा & $11028 \mathrm{U}$ & $14.70 \%$ & $0.58 \mathrm{Rt}^{-1}$ & 6S.9AN & 30341 AJ & $17.54 \%$ \\
\hline 8 & $0.59 \mathrm{Rt}$ & $86.2 \mathrm{AU}$ & $0.64 \mathrm{RI}$ & 285.4 JU & $34.05 \%$ & $0.70 \mathrm{nt}$ & $5.4 \mathrm{AU}$ & $58522 \mathrm{AJ}$ & $4452 \%$ \\
\hline 10 & o $31 \mathrm{HA}$ & 5 rAl & $9.75 R t$ & 20зми & $348 \%$ & $\mathrm{DTEH}$ & $15.0 \mathrm{All}$ & प्रE6 TAJ & $419 \%$ \\
\hline 11 & $0.79 \mathrm{RA}$ & $5.1 \mathrm{AL}$ & $0.00 \mathrm{RI}$ & $172=0$ & $2.05 \%$ & $0.85 \mathrm{R}^{4}$ & $2.3 \mathrm{AU}$ & 446 Q.AJ & $202 \%$ \\
\hline
\end{tabular}

Irect: 16, ID ki.Wostosth wisus ctums

\begin{tabular}{|c|c|c|c|c|c|c|c|c|c|}
\hline Peak & $\begin{array}{c}\text { Start } \\
\text { Position }\end{array}$ & $\begin{array}{l}\text { Start } \\
\text { Heiaht }\end{array}$ & $\underset{\text { Pasition }}{\text { Wax }}$ & $\begin{array}{l}\text { Mex } \\
\text { Height }\end{array}$ & $\begin{array}{c}\operatorname{Max} \\
5\end{array}$ & $\begin{array}{c}\text { End } \\
\text { Position }\end{array}$ & $\begin{array}{l}\text { End } \\
\text { Height }\end{array}$ & Ares & $\begin{array}{c}\text { Ares } \\
\&\end{array}$ \\
\hline 1 & $0.100 \mathrm{Rf}$ & $464 \mathrm{U}$ & $0.00 \mathrm{Rf}$ & $27.4 \mathrm{AU}$ & $451 \%$ & $0.07 \mathrm{Ff}$ & $0.2 \mathrm{AN}$ & S03.0 AN & $237 \%$ \\
\hline 2 & a $\| R$ & 2.1 A. & $0.14 \mathrm{RI}$ & 14.0AL & $230 \%$ & $0.12 \mathrm{Rf}$ & $0.6 \mathrm{AL}$ & $348.6 \mathrm{AL}$ & $1.83 \%$ \\
\hline 8 & $0.20 \mathrm{Rf}$ & $0.1 \mathrm{AU}$ & $0.20 \mathrm{Rf}$ & TO.5AU & $1161 \%$ & $0.22 \mathrm{Rf}$ & $57.4 \mathrm{AN}$ & $2504.9 \mathrm{AN}$ & $11.84 \%$ \\
\hline 4 & $0.32 \mathrm{Rr}$ & $5 ? 4$ All & $0.37 \mathrm{RI}$ & $142.1 \mathrm{All}$ & 23394 & $0.49 \mathrm{RI}$ & $24.7 \mathrm{ALI}$ & 5800 B ALL & $2732 \%$ \\
\hline 5 & $0.43 \mathrm{Rf}$ & $24.8 \mathrm{AU}$ & $0.40 \mathrm{Rf}$ & $175.3 \mathrm{AN}$ & $2936 \%$ & $0.52 \mathrm{Ff}$ & $27.2 \mathrm{AN}$ & 4419.8 AN & $20.02 \%$ \\
\hline 6 & $0.52 \mathrm{RI}$ & 274 A Al & $0.58 \mathrm{RI}$ & $142.1 \mathrm{AL}$ & 28404 & $0.65 \mathrm{RI}$ & 18.9 AL & $6598.5 \mathrm{ALL}$ & $310 \%$ \\
\hline 7 & $0.60 \mathrm{Rf}$ & $17.14 \mathrm{U}$ & $0.67 \mathrm{Rf}$ & $21.6 \mathrm{AU}$ & $356 \%$ & $0.73 \mathrm{Rf}$ & $6.5 \mathrm{AN}$ & $603.5 \mathrm{AN}$ & $2.22 \%$ \\
\hline 8 & $0 . S B R I$ & 29 All & $0.58 \mathrm{RI}$ & $11.4 \mathrm{AL}$ & $188 \%$ & 1. $\cos \Omega f$ & $0.8 \mathrm{AL}$ & $345.4 \mathrm{ALI}$ & $1.83 \%$ \\
\hline
\end{tabular}

\begin{tabular}{|c|c|c|}
\hline Peak & $\begin{array}{c}\text { Maximum position } \\
\text { (Rention factor) }\end{array}$ & \% of area \\
\hline 1 & 0.03 & 2.37 \\
\hline 2 & 0.14 & 1.63 \\
\hline 3 & 0.30 & 11.94 \\
\hline 4 & 0.37 & $\mathbf{2 7 . 3 2}$ \\
\hline $\mathbf{5}$ & $\mathbf{0 . 4 8}$ & $\mathbf{2 0 . 8 2}$ \\
\hline 6 & 0.56 & $\mathbf{3 1 . 0}$ \\
\hline 7 & $\mathbf{0 . 6 7}$ & $\mathbf{3 . 2 2}$ \\
\hline $\mathbf{8}$ & $\mathbf{0 . 9 6}$ & $\mathbf{1 . 6 3}$ \\
\hline
\end{tabular}

Figure 6: Densinometric scan of Mukhadooshikahara churna at $620 \mathrm{~nm}$

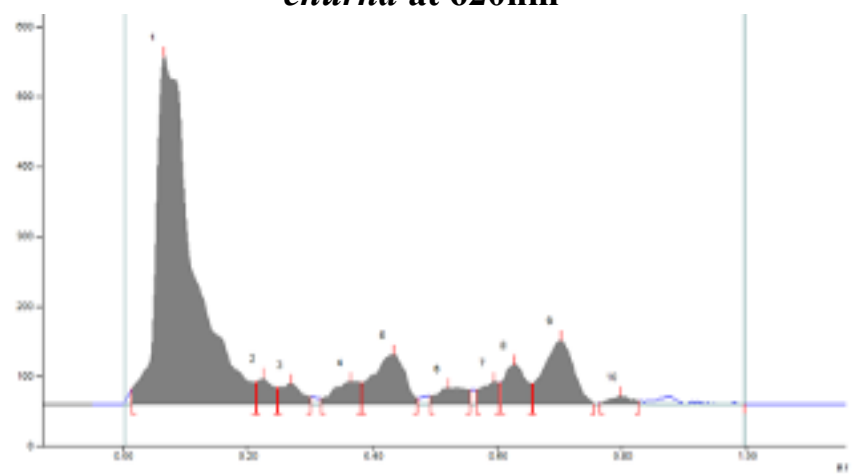




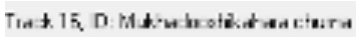

\begin{tabular}{|c|c|c|c|c|c|c|c|c|c|}
\hline Peak & $\mid \begin{array}{c}\text { Start } \\
\text { Poxition }\end{array}$ & $\begin{array}{c}\text { Start } \\
\text { Height }\end{array}$ & $\begin{array}{c}\text { Mex } \\
\text { Deaitien }\end{array}$ & $\underset{\text { Height }}{\operatorname{Mex}}$ & $\operatorname{Mex}_{4}$ & $\begin{array}{c}\text { End } \\
\text { Position }\end{array}$ & $\begin{array}{c}\text { End } \\
\text { Height }\end{array}$ & Area & $\begin{array}{c}\text { Aree } \\
\%\end{array}$ \\
\hline 1 & $0.01 \mathrm{Rf}^{\circ}$ & $21.1 \mathrm{AJ}$ & $007 \mathrm{R}^{\circ}$ & $495.5 \mathrm{All}$ & $06.35 \%$ & $0.21 \mathrm{Rf}^{\circ}$ & $50.7 \mathrm{AU}$ & $21175.3 \mathrm{AV}$ & $65.61 \%$ \\
\hline 2 & $0.21 \mathrm{Rf}$ & $312+J$ & $023 \pi$ & $37.1 \mathrm{All}$ & $4.21 \%$ & $0.25 \mathrm{Rf}$ & $23.2 \mathrm{AU}$ & 673.7 AU & 2.298 \\
\hline 3 & $0.25 \mathrm{Rr}$ & $206 \mathrm{NJ}$ & $027 \mathrm{H}^{\circ}$ & $28.5 \mathrm{mN}$ & $3.5 \%$ & V2 Rt & $8.7 \mathrm{hl}$ & 700380 & $2.16 \%$ \\
\hline 1 & $0.32 \mathrm{Rf}$ & 8.1AJ & $0.37 \mathrm{R}^{2}$ & $322 \mathrm{AU}$ & $3.66 \%$ & $0.33 \mathrm{Rf}^{\circ}$ & $32.5 \mathrm{AU}$ & $953.94 \mathrm{U}$ & $2.96 \mathrm{~s}$ \\
\hline 5 & $0 . \$ 8 \mathrm{Rf}$ & sa 2 Aa & $\mathrm{D} 44 \mathrm{~A}$ & Z1SAL & $8.11 \%$ & $047 \mathrm{RF}$ & 8EAll & $25812 \mathrm{All}$ & 7344 \\
\hline 8 & $0.69 \mathrm{Rt}$ & $11.5 \mathrm{AJ}$ & $002 \mathrm{R}^{\circ}$ & $22.2 \mathrm{AN}$ & $263 \%$ & $0.06 \mathrm{Rt}^{\circ}$ & $19.6 \mathrm{AU}$ & $300.6 \mathrm{AV}$ & $2.40 \%$ \\
\hline 7 & $0.57 \mathrm{Rf}$ & נلג & $080 \mathrm{n}$ & $321 \mathrm{AL}$ & $3.85 \%$ & $0.83 \mathrm{RP}$ & 32.441 & $647.3 \mathrm{AU}$ & $2.21 \mathrm{~s}$ \\
\hline 8 & $0.61 \mathrm{Rt}$ & $306 \mathrm{NJ}$ & $063 \mathrm{H}^{\circ}$ & $56.6 \mathrm{AN}$ & $623 \%$ & $0.06 \mathrm{Rr}$ & $206 \mathrm{nu}$ & $1381.8 \mathrm{AJ}$ & $132 \%$ \\
\hline 9 & $0.68 \mathrm{Rf}$ & $28.94 J$ & $070 \mathrm{R}^{4}$ & $90.7 \mathrm{AU}$ & $10.32 \%$ & $0.76 \mathrm{Rf}^{\circ}$ & $0.2 \mathrm{AU}$ & 3277.640 & $9.54 \%$ \\
\hline 10 & $037 \mathrm{Rf}$ & 1. A. & 1186 $\mathrm{A}$ & 11 SAL & $128 \%$ & $083 \mathrm{Rf}$ & 43All & 282.1 All & $0.8 \mathrm{~s}<$ \\
\hline
\end{tabular}

\begin{tabular}{|c|c|c|}
\hline Peak & Maximum Position & \% Area \\
\hline 1 & 0.07 & 65.61 \\
\hline 2 & 0.23 & 2.09 \\
\hline 3 & 0.27 & 2.18 \\
\hline 4 & 0.37 & 2.96 \\
\hline 5 & 0.44 & 7.94 \\
\hline 6 & 0.52 & 2.48 \\
\hline 7 & 0.60 & 2.01 \\
\hline 8 & 0.63 & 4.32 \\
\hline 9 & 0.70 & 9.54 \\
\hline 10 & 0.80 & 0.89 \\
\hline
\end{tabular}

\section{Discussion}

\section{Pharmaceutical study}

The reference of Mukhadooshikahara lepa churna was taken from Astanga Hrudaya and the churna was prepared out of Lodhra, Vacha, Dhanyaka, Vatapallava and Narikela shuktya. Raw vatapallava and Narikela Shuktya was collected and dried under sunshade to avoid moisture content in final product. Lodhra, Vacha and Dhanyaka were collected in dry form and washed and dried once again to remove physical impurities. All the raw dried drugs were weighed initially separately in order to calculate loss at the final product. Dried Lodhra was found difficult to pound and there was loss in the final stage of preparation of churna due to its fibrous nature. Pounding of vacha was comparatively easier than Lodhra indicating the hardness of the drug. Aromatic odour was appreciated for vacha and Dhanyaka due to the volatile oils present in the dravya and coriandroil. Dried vata pallava was light in weight and easy to pound. Narikela shuktya was light in weight and having more density and easily pounded. The final product of all these ingredients were coarse powder and it was brownish white in colour with characteristic odour.

\section{Analytical study pH}

The $\mathrm{pH}$ of the churna is 5.69 which is weakly acidic. $\mathrm{pH}$ as a measure of the hydrogen-ion activity is important from the standpoint of stability or physiological suitability. The optimal $\mathrm{pH}$ of face and body lies between 4.7 to 5.75 . Hence the churna will not have irritant effect and can be used for external application.

\section{Loss on drying}

The value is 7.21 which indicate the moisture content in the churna. Less the moisture content more stable and more moisture and less stable.

\section{Total ash}

The value is $9.99 \pm 0.02$. The residue remaining after incineration is the ash content of the drug. It indicates the purity and identity of raw drugs.

\section{Acid insoluble ash}

It is a part of total ash which is insoluble in dilute HCl. In mukhadooshika hara Lepa churna 1.67 $\pm 0.02 \%$ will soluble in water.

\section{Water soluble ash}

It is a part of total ash which is soluble in water. In mukhadooshikahara Lepa curna $2.77 \pm 0.01 \%$ will soluble in water. These total ash, acid insoluble ash and water soluble ash indicate the purity and identity of raw drugs.

\section{Alcohol soluble extractive}

This value is applied for the drugs which contain alcohol soluble constituents such as tannins, resins and alkaloids, thus helps to know active principles. The obtained value is $6.50 \pm 0.01 \%$. Lodhra (13), vacha (14) and vatapallava (15) contains tannins and alkaloids.

\section{Water soluble extractive}

Water soluble extractives indicate water soluble constituents such as tannins, sugars, plant acids and mucilage. Mukhadooshika hara churna has $11.14 \pm$ $0.01 \%$ water soluble extractive because of tannin content in Lodhra, vacha and vata and also due to the mucilage content in vacha.

\section{HPTLC photo documentation:}

The prepared churna was subjected to HPTLC fingerprinting at different wavelengths $(254 \mathrm{~nm}, 366$ and $620 \mathrm{~nm})$. This study reveals the chemical fingerprint profile of the test samples. In the present study mukhadooshikahara churna was assessed at selected UV regions wavelength (at $254 \mathrm{~nm} 366 \mathrm{~nm} \& 620 \mathrm{~nm}$ ). The colour spots observed indicates the presence of different components in the sample. It acts as fingerprint of the used sample, which can be used as reference for the preparation of curna. At $254 \mathrm{~nm}, 366 \mathrm{~nm}$ and $620 \mathrm{~nm} \mathrm{11}$, 8 and 10 peaks were found with different retention factor starting from 0.02 to $0.80,0.03$ to 0.096 and 0.07 to 0.80 respectively. The bands at different $\mathrm{Rf}$ value indicate the presence of particular active compounds in mukhadooshikahara churna.

\section{Conclusion}

Mukhadooshikahara lepa churna is a simple preparation and can be prepared by easily available drugs. In this research work an attempt was made to prepare the Mukhadooshikahara churna out of Lodhra, Vacha, Dhanyaka, Vatapallava and Narikela shuktya. The Churna was prepared by general method of preparation of Churna. The prepared Mukhadooshikahara lepa curna was subjected to organoleptic and analytical study. Analytical studies and HPTLC conducted on the study drug have helped to develop preliminary standards for 
Mukhadooshikahara Lepa churna. The results of physico-chemical parameters and HPTLC can be taken as preliminary standards, purity and equinity of mukhadooshikahara lepa churna. Number of peaks seen in HPTLC photo documentation can be taken as combination of constituents present in the ingredients of mukhadooshikahara lepa.

\section{References}

1. Vasan S, Ashwinikumar M. Lepa and its application. Health and Medicine[Internet] : Available from : https://www.slideshare.net/mobile/ PanchakarmaSdmcahhass/lepa-and-its-application dated 20/08/2021 time 20:32IST

2. Sharma P V. Astangahrudaya of Vagbhata with Sarvangasudara and Ayurvedarasayana commentaries. Reprint 2011 edition. Pune: Chaukambha Sanskrit Sansthan; 2011: 890p.

3. R Jyothi. A comparative study on efficacy of nasya karma and lepa in mukhadhooshika w.s.r to acne vulgaris. Post Graduate Thesis. Department of Panchakarma. Bangalore: Rajiv Gandhi University of Health Sciences, Karnataka; 2011. Available from: http://www.rguhs.ac.in/cdc/onlinecdc/ uploads/03_A035_23619.doc dated 20/08/2021 time 20:38 IST

4. Thriveni D.P.,Kishore R. K., Shrinivasan H T, M Ashalatha. A comparative study of the efficacy of kolaphalamajja and shalmalikantaka on mukhadhooshika. IJAAR [Internet]. July 9; 2 (2): [257-265]. Available from: https://www.ijaar.in/

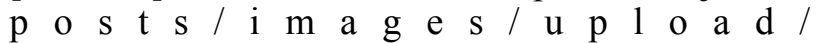
VOL_II_ISSUE_II_JUL_AUG_257_265.pdf

5. Angadi Ravindra. A text book of Bhaishajya kalpana Vijnana pharmaceutical science. Varanasi. Chaukambha Surabharati Prakashini; Second revised edition: 2016; P-85.

6. CCRAS. Laboratory Guide for the Analysis of Ayurveda and Siddha Formulation. 1st ed. New
Delhi. Dept. of AYUSH, Ministry of Health and Family Welfare, Govt. of India; 2010.p.28.

7. CCRAS. Laboratory Guide for the Analysis of Ayurveda and Siddha Formulation. 1 ${ }^{\text {st }}$ ed. New Delhi. Dept. of AYUSH, Ministry of Health and Family Welfare, Govt. of India; 2010.p.28

8. CCRAS. Laboratory Guide for the Analysis of Ayurveda and Siddha Formulation. 1st ed. New Delhi. Dept. of AYUSH, Ministry of Health and Family Welfare Govt. of India; 2010.p.30.

9. CCRAS. Laboratory Guide for the Analysis of Ayurveda and Siddha Formulation. 1 ${ }^{\text {st }}$ ed. New Delhi. Dept. Of Ayush Ministry of health and Family Welfare Govt. of India; 2010.p.29.

10. CCRAS. Laboratory Guide for the Analysis of Ayurveda and Siddha Formulation. 1 $1^{\text {st }}$ ed. New Delhi. Dept. Of Ayush Ministry of health and Family Welfare Govt. of India; 2010.p.42.

11. CCRAS. Laboratory Guide for the Analysis of Ayurveda and Siddha Formulation. 1st ed. New Delhi. Dept. Of Ayush Ministry of health and Family Welfare Govt. of India; 2010.p.28.

12. CCRAS. Laboratory Guide for the Analysis of Ayurveda and Siddha Formulation. 1st ed. New Delhi. Dept. Of Ayush Ministry of health and Family Welfare Govt. of India; 2010. p.92.

13. The Ayurvedic Pharmacopeia of India. Ministry of Health and Family Welfare. Government of India. National Institute of Science and Communication. New Delhi Reprinted 2001: P 113

14. The Ayurvedic Pharmacopeia of India. Ministry of Health and Family Welfare. Government of India. National Institute of Science and Communication. New Delhi Reprinted 2001: P 178

15. The Ayurvedic Pharmacopeia of India. Ministry of Health and Family Welfare. Government of India. National Institute of Science and Communication. New Delhi Reprinted 2001: P 119 